
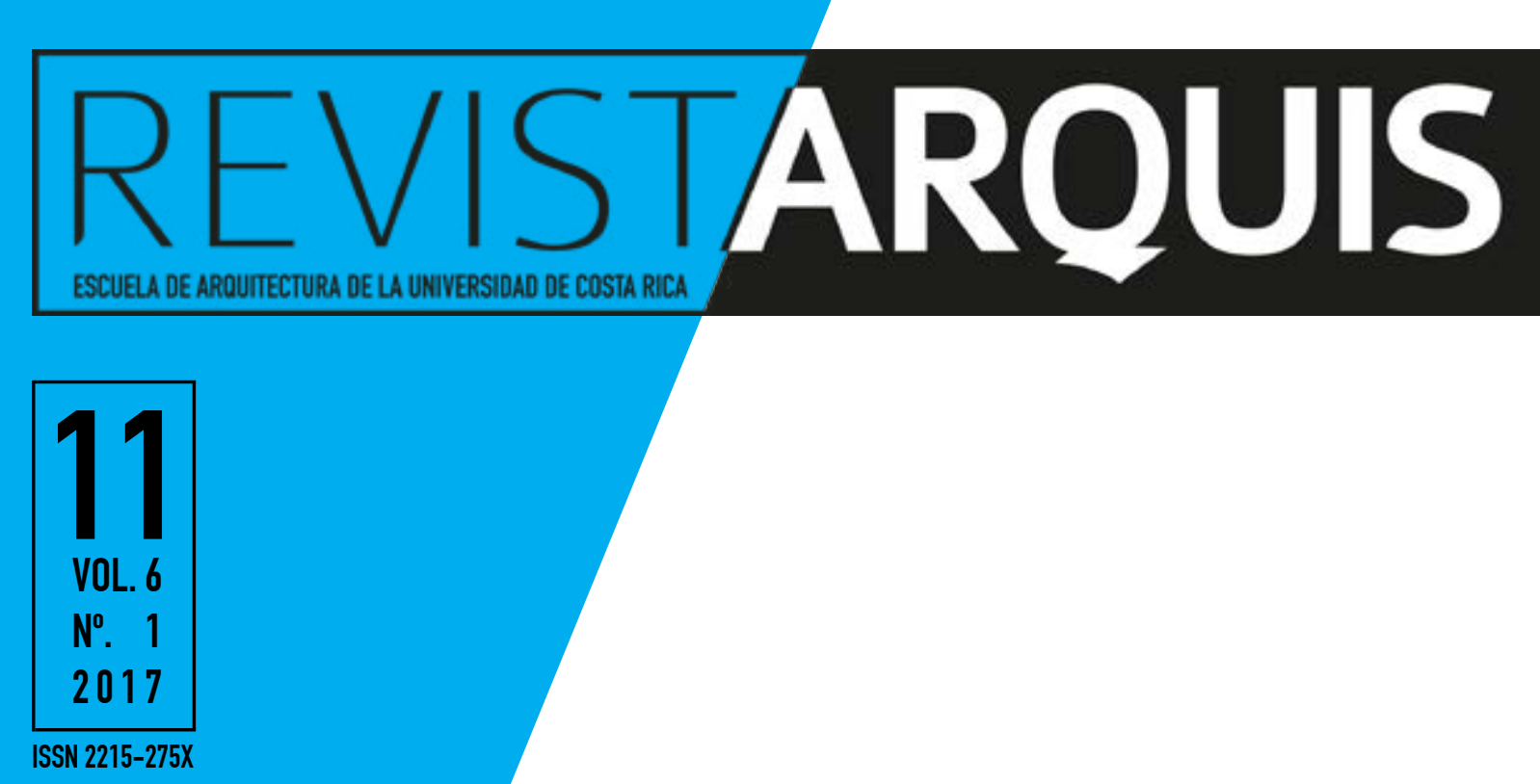

\begin{abstract}
6_ Towards a territorial praxis José Alfredo Ramírez Galindo

Clara Olóriz Sanjuán

Reseña | 48-58
\end{abstract}

7_ Littoral Negotiations

Liam Mouritz, Chan Ting Fu

Xiabin $\mathrm{Hu}$,

AA Landscape Urbanism

Reseña | 59-79

8_Parque de la Libertad, Pavas, San José, Costa Rica

Luis Diego Alpízar Valverde

Tatiana Arguedas Araya

Proyecto académico | 80-85

9 Coopeprocesadora de infusiones naturales de la zona del caribe de Costa Rica Harold Jiménez Quesada

Proyecto académico | 86-89 


\title{
Littoral Negotiations
}

\author{
Liam Mouritz \\ Chan Ting Fu \\ Xiabin $\mathrm{Hu}$ \\ AA Landscape Urbanism
}

Reseña

Invitados internacionales

Architectural Association School of Architecture

\section{http://groundlab.org/}

Recibido: 22 de abril del 2016

Aceptado: 31 de marzo del 2017

\section{Liam Mouritz}

Architect in Landscape Architecture / The University of Western Australia and MA Landscape Urbanism Graduate / Architectural Association School of Architecture. He is part of the Groundlab -AA.

\section{Chang Ting Fu}

Designer in the field of Architecture and urban planning / National Cheng Kung University - Taiwan, recently completing studies of MA Landscape Urbanism at the Architectural Association School of Architecture - London. He is part of MAD architect Beijing - China.

\section{Xiabin Hu}

Architect and MA Landscape Urbanism Graduate.

\section{AA Landscape Urbanism MArch/MSc}

London, United Kingdom

AA Landscape Urbanism is a Graduate programme by the Architectural Association. It offers a MArch (16 months) /MSc (12 months) degree awards. The programme is studio-based and explores how the techniques, dynamics and discourses of landscape-based disciplines can be re-appropriated as a means to ask fundamental questions about the contemporary city. It investigates the how the intersection of physical and social processes of territorial formation generates new forms of urban typologies, governance and knowledge.

landscapeurbanism.aaschool.ac.uk

\section{Resumen}

Este Proyecto explora la borrosa interfaz entre tierra y mar, área conocida como litoral. El material que primordialmente constituye tal condición es la arena húmeda, o sedimento. Dicho material sirve de partida para la contemplación de escenarios para el diseño que son alternativos para la zona litoral del Mar Mediterráneo. Paralelo a ello, ambiciona formas en las cuales el papel del arquitecto puede ser mejorado y en las cuales el diseño puede volverse una herramienta relevante para la producción en los litorales. Littoral Negotiations Project se presenta como una especulación acerca del rol del arquitecto, la implementación del diseño y las potenciales consecuencias que podría tener en la generación de escenarios alternativos, para un contexto y territorio específicos: el Mar Mediterráneo.

Palabras clave: Arquitectura; diseño; litoral; mar mediterráneo; territorio.

\section{Abstract}

This project explores the blurred interface between the land and the sea known as the littoral zone. The very matter from which this condition is constructed is wet sand or sediment. This is the material from which to begin and envisage alternative design scenarios for the littoral zone of the Mediterranean Sea. Parallel to this, the project envisions ways in which Architect's agency could be enhanced and design can be a relevant tool for the production of littoral zones. Littoral Negotiations Project is presented here as a speculation of the role of the architect, the implementation of design and the potential outcomes it can have in the generation of alternative scenarios for a specific context and territory within the Mediterranean Sea.

Keywords: architecture; design; littoral; mediterranean sea; territory. 
$\mathrm{T}$

he AA Landscape Urbanism (AALU) is a Graduate programme of the Architectural Association that explores 'TERRITORY' as a field of DESIGN PRAXIS'. It aims at expanding the role of architects out of their disciplinary confinements, the projective use of landscape understood as a social construct/artifice and the re-definition of the urban beyond conventional models (i.e. city-megacities-metropolis models) through the use of territory as a conceptual model.

In doing so, the programme explores the types of project, forms of documentation, theories, technologies and techniques required to rethink and redefine the temporal production of territorial spaces through the praxis of design.

The course combines material explorations of landscape evolution (facilitated by digital simulations) with the development of critical perspectives and studio work. It is aimed at professionals - architects, landscape architects, engineers, urban planners and geographers - who are engaged/interested with territorial disciplines.

This is a graduate final project made by the architects in the Master Degree Program of Landscape Urbanism of the Architectural Association between January to September 2015, it took 9 months structured as a design/theoretical exercise.

Littoral Negotiations explores the blurred interface between the land and the sea known as the littoral zone. The very matter from which this condition is constructed is wet sand or sediment. This is the material from which we begin to envision alternative design scenarios for the littoral zone of the Mediterranean Sea which are driven by a detailed understanding of coastal geomorphology and the way people occupy coastal landscapes. We acknowledge the idea of the 'Anthropocene', in which human influences characterize a distinct layer of the geologic record. In this new era, humans have the capacity to hack the environmental processes which govern the form of the earth's surface. In our case, the processes which we suggest should be controlled are those which mould the planets shifting, sedimentary coastal zones.

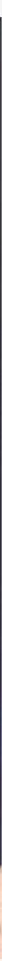

1973

aerial_2015 > 


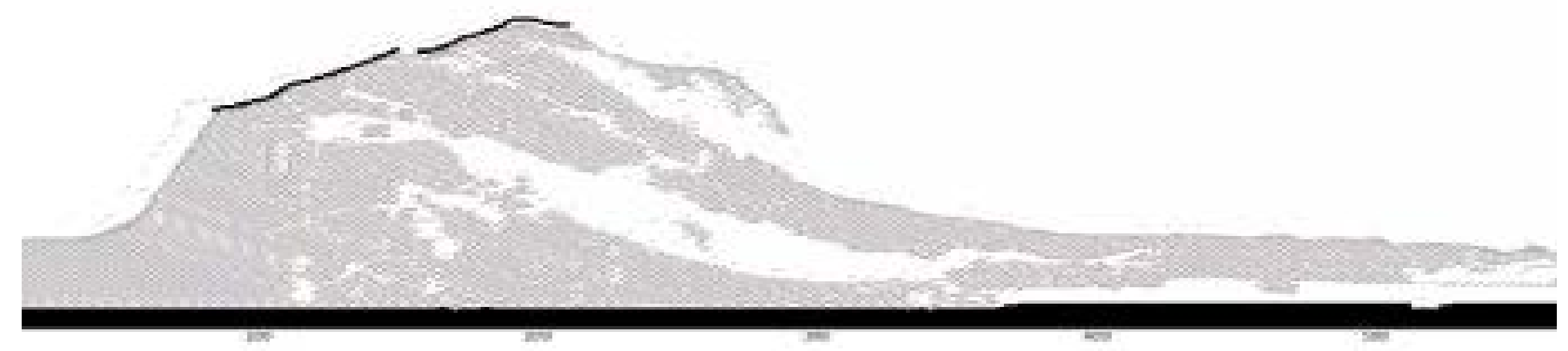

In the Mediterranean Sea, sediment is in short supply, largely due to the damming of its many rivers. The sediment that does make it to the ocean, flows via littoral cells along the coast, crossing the borders of 25 different nations and affecting almost half a billion people that live along the Mediterranean Coast. This cross-political situation has forced numerous conflicts and cooperation's, in which any sand extraction or intervention within the coast will invariably have some impact on the downstream region. Despite this, there exists no Mediterranean Scale action plan, framework, or precedents in how to manage sediment, as exists with other important resources and issues such as the management of fisheries, or the management of pollution on a Mediterranean Scale, as dictated by multi-national agreements such as the Barcelona Convention. Focusing on the erosive littoral zone of Lake Manzala, situated between the mouths of the Nile River and the Suez Canal, we developed scenarios and strategies of sediment negotiation and redistribution in which land expansion begins to reconfigure new territory. We developed our project as a kind of prototype for sediment management which reveals the need for a charter for sediment management and begin to suggest how that might work. 


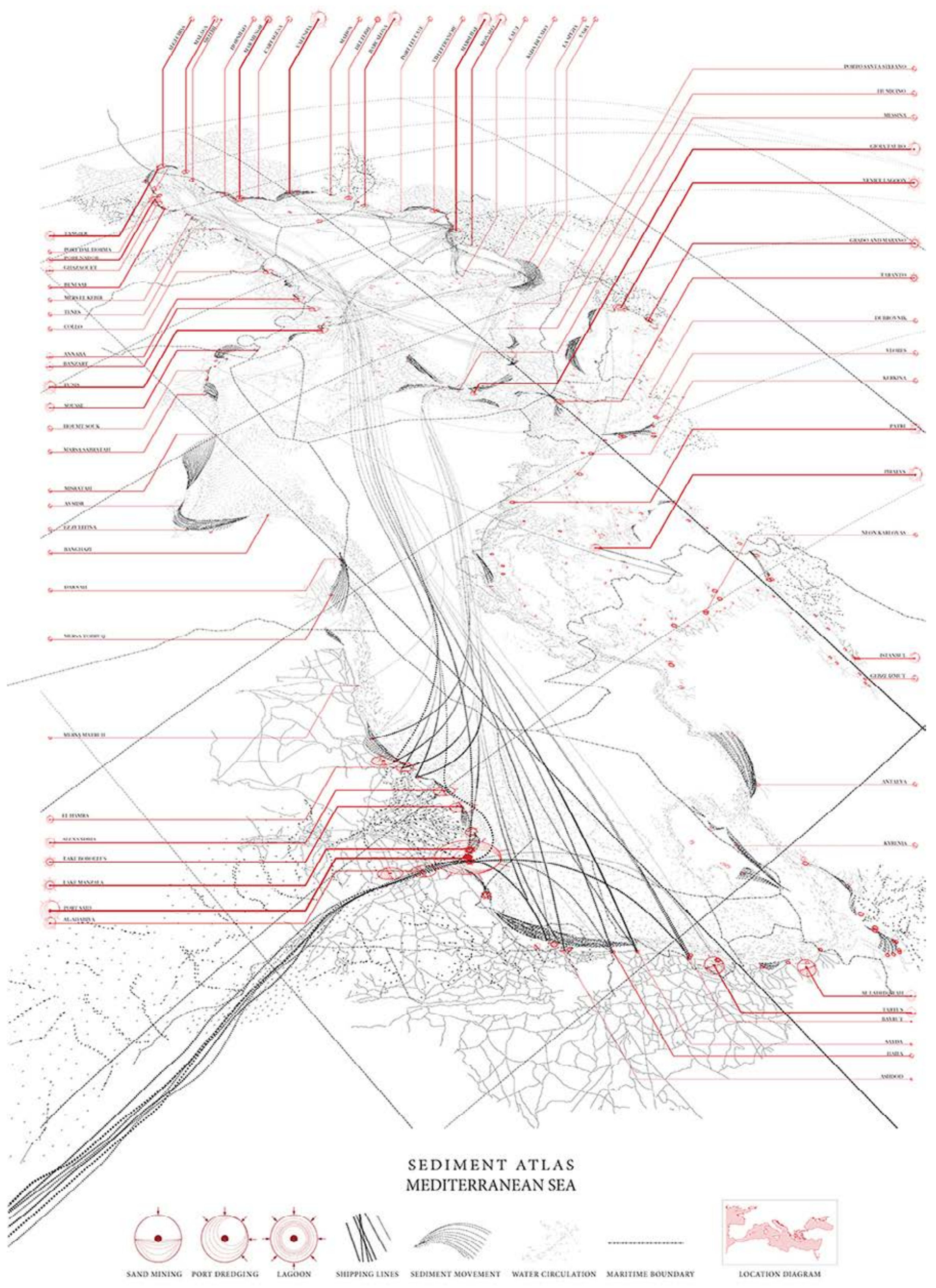

01_Atlas A 

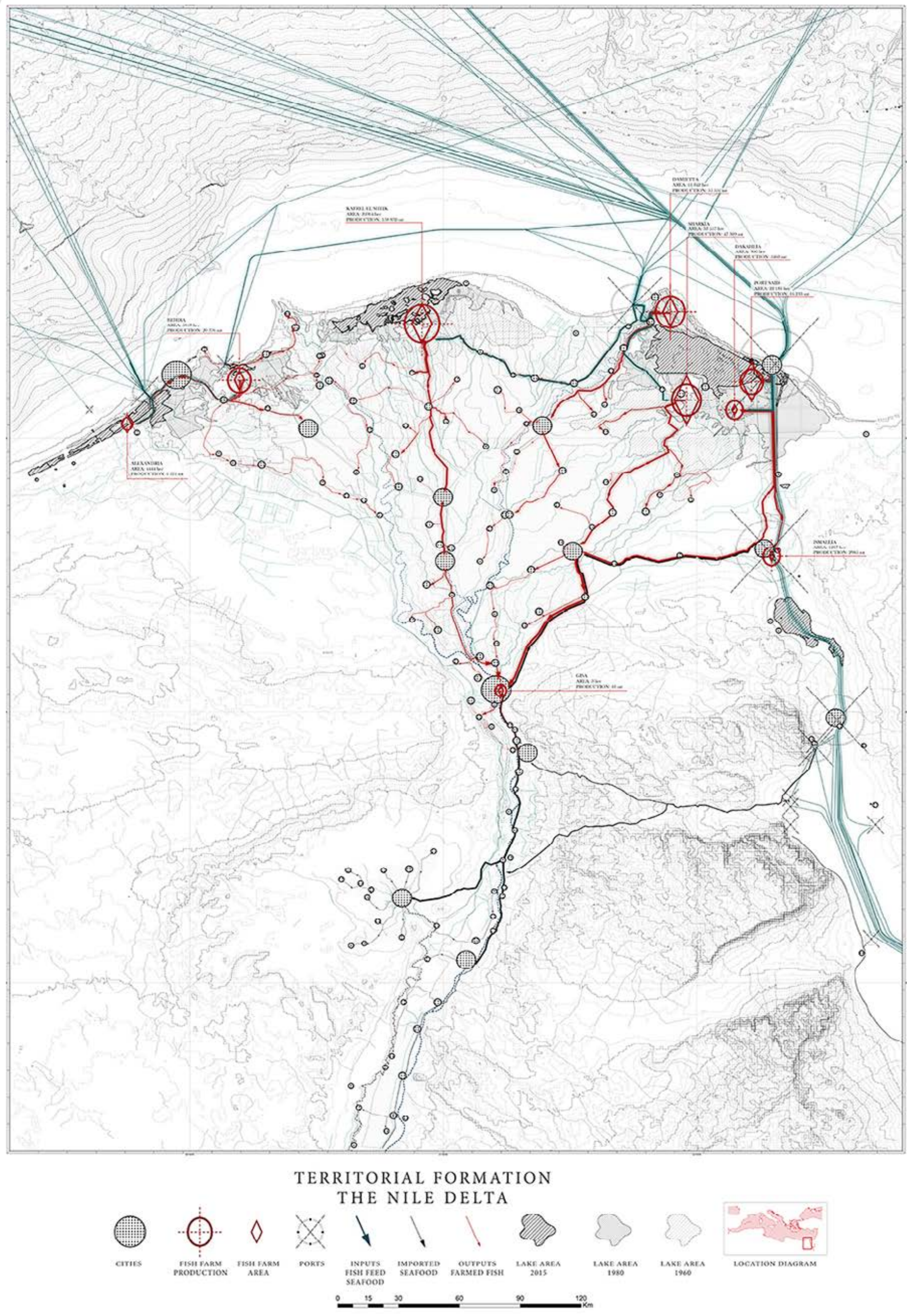


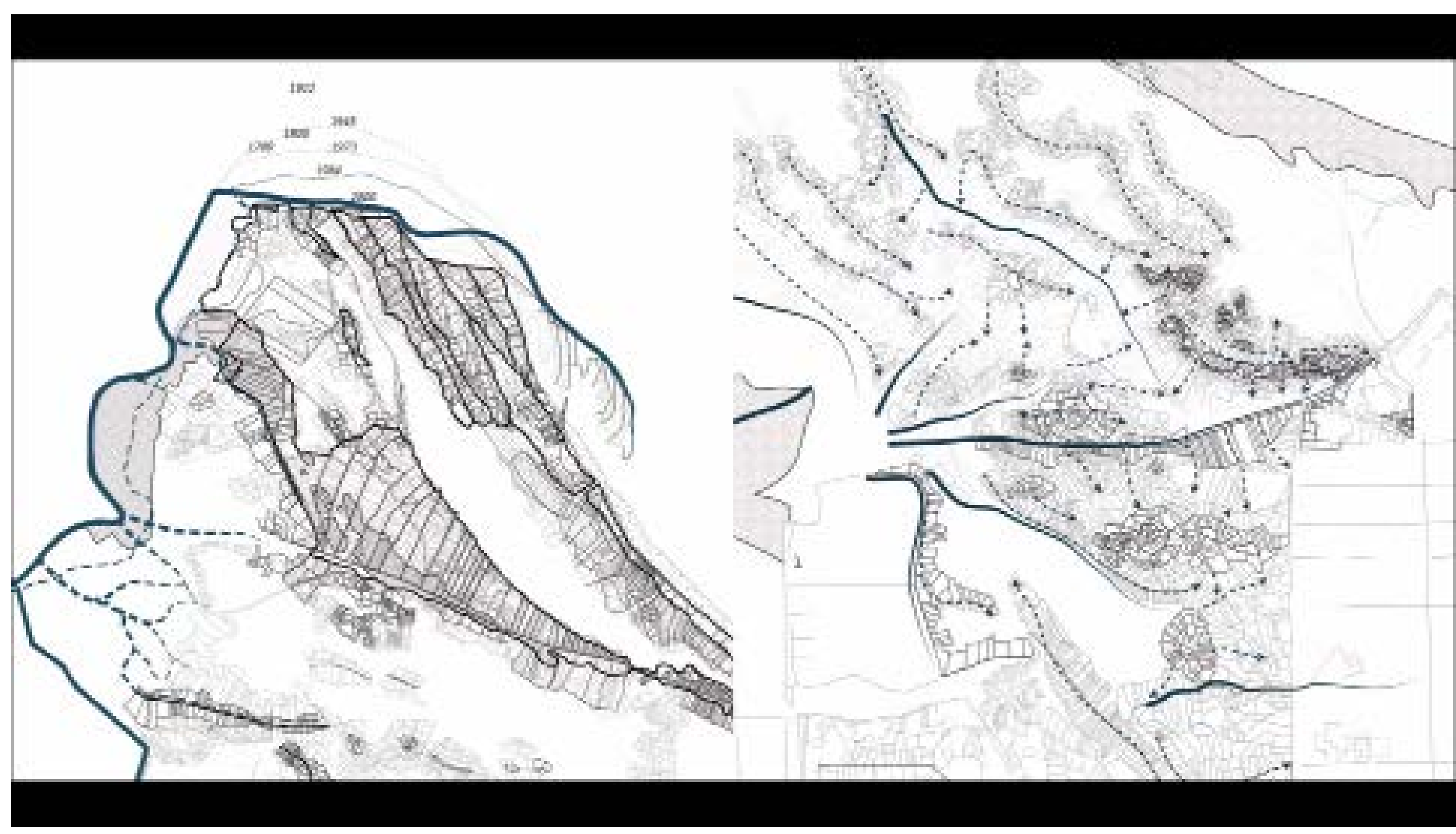

Video Lake Manzala Evolution A

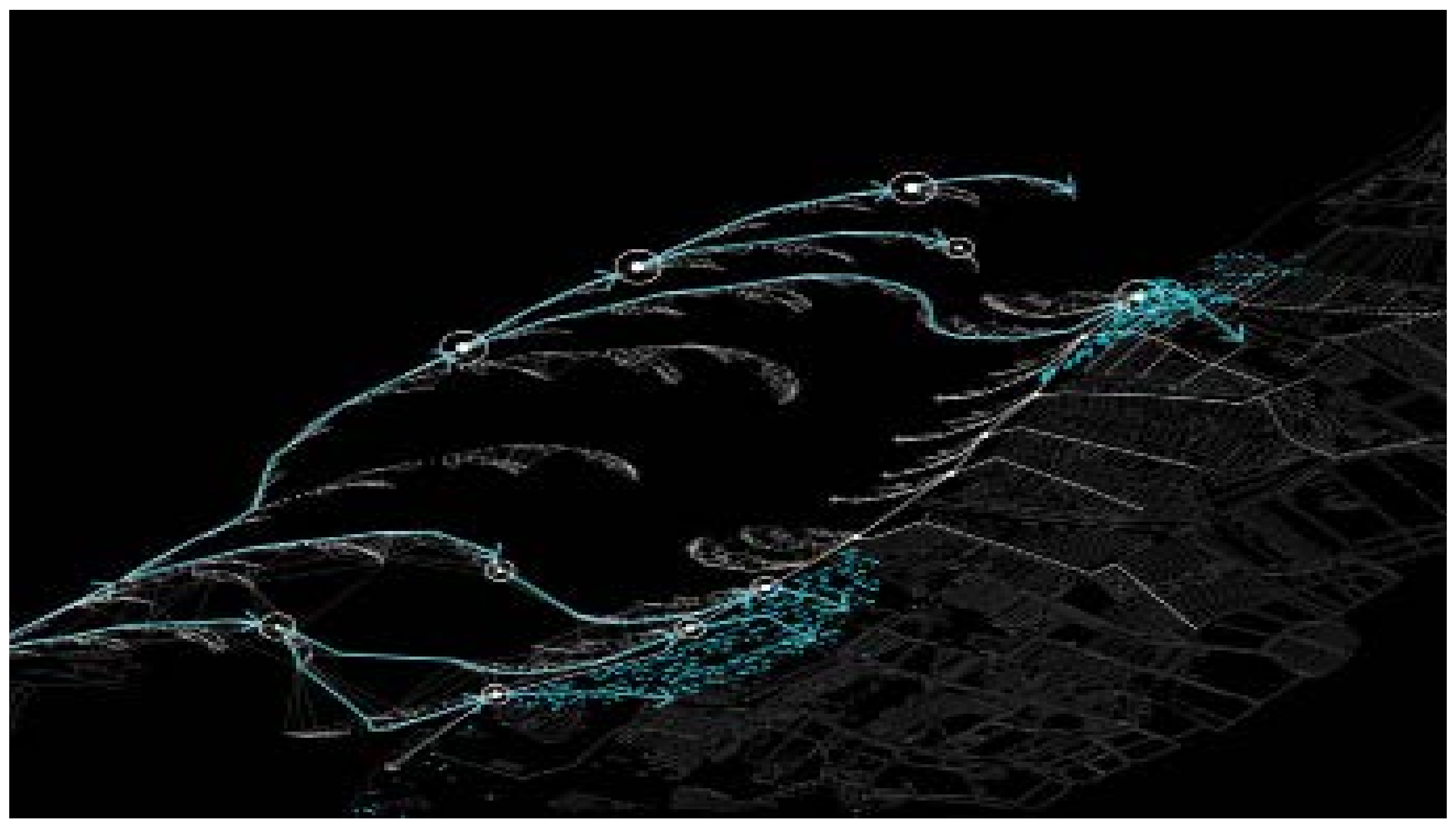




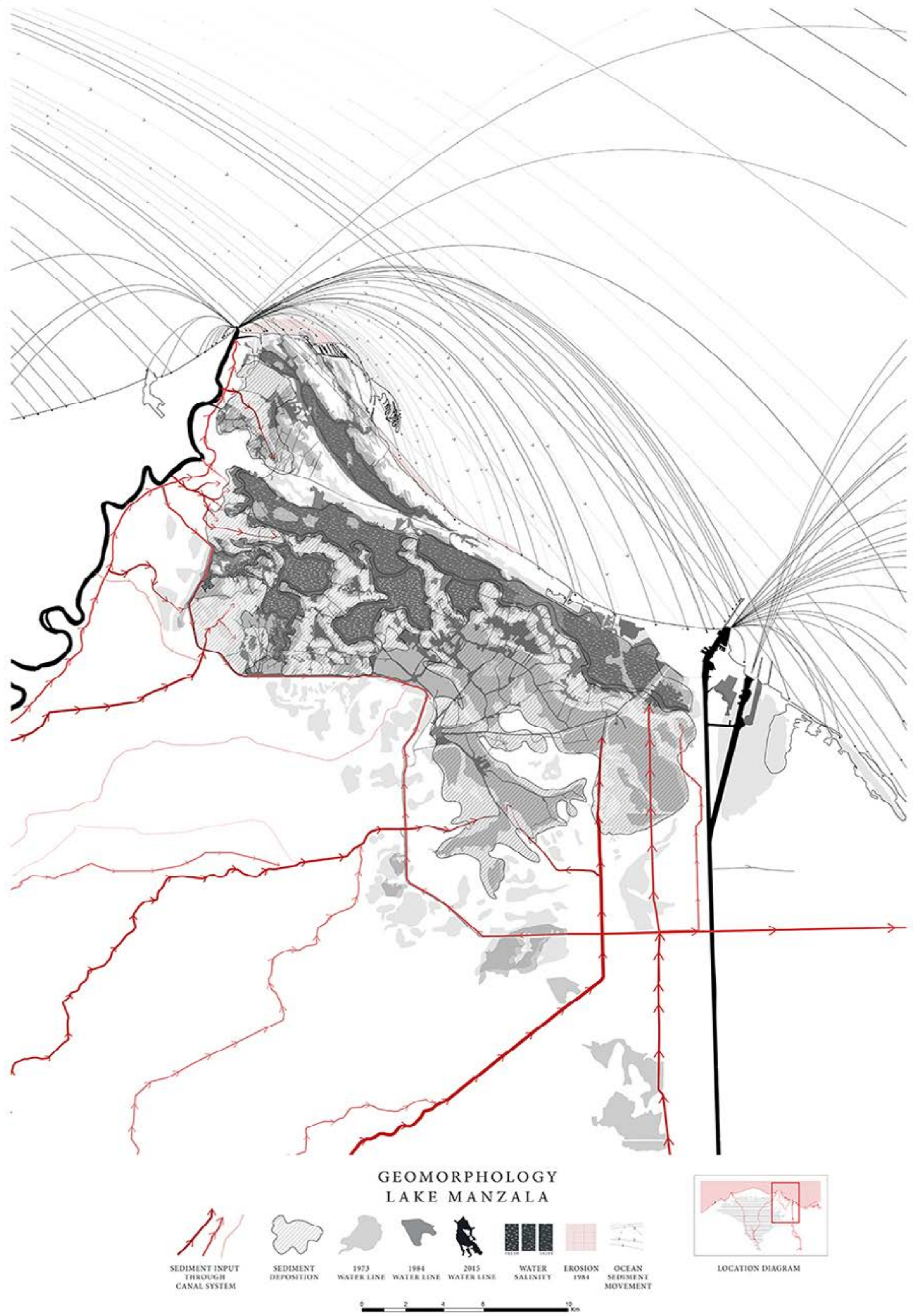


Sediment seems a vague term, defined as the solid that settles to the bottom of a liquid, the dregs. It implies a ground crossing the divide between the liquid and the solid, or perhaps more pertinently, the ocean and the land. It can be all around you when swimming in the ocean, and yet you can't see it as it lacks solidity. However, it also has significant economic power. It can be both a nuisance and a highly valuable resource. Ports around the world are constantly trying to get rid of it, through dredging activities, while at the same time other places requiring more land demand more of it. Its malleability makes it both unpredictable and unstable. Being granular, somewhere between the liquid and the solid, it can be transported by the barge or by the sandbag. With enough supply of sediment, it can begin to form into something most fundamental and useful to capitalist production: land itself. It is in this reconfiguring and settling of ground, in which territories themselves are altered, an adjustment of land demanding the skills of a designer to cross disciplinary boundaries, making use of different tools as a means to ask fundamental questions about the world and project alternative futures.

Our project was developed through the two main toolsets, that of cartography and scripting. Our cartographies aimed to invert traditional understandings of the territory as a way to reveal future scenarios. At a variety of scales, we explored the implications of both moving sediment (both through human and non-human forces) and the various intricacies and political mechanisms driving the fish farming industry throughout the Nile Delta. All our cartographies seek to represent these issues in time, highlighting the processual nature of them as key to any intervention or future strategy. These cartographies were backed with the rigour of our own abstract simulations, taking advantage of the scientific disciplines we acquired the Coastal Evolution Model to simulate the movement of a coastal spit and how it might interact with any number of obstacles, forming different patterns of lagoons and islands. These simulations were done less with the quantitative supremacy of professional simulations, but with a speculative desire to see what might be the potential for a series of obstacles placed in a variety of different angles. We learnt from the simulation how moving sediment might be massaged and manipulated, gaining some level of control over how it consolidates or erodes.

Through our research, we grappled with a wide variety of interests, which we developed over the course of the year. Perhaps, above all what we hoped to be put forward is an example of a territorial practice which articulates the "conflicts, struggles, alterations, and shifts" which are inherent to any future intervention within a territory (Ramirez and Castro 2015 p.145). In the case of coastal territories, such as Lake Manzala, the shifting ground has significant implications for the various different social groups which exist there. While each group seems to be in conflict with each other, any strategy for the site should acknowledge these differences and consider any possible mutually beneficial outcomes from any proposed intervention. 


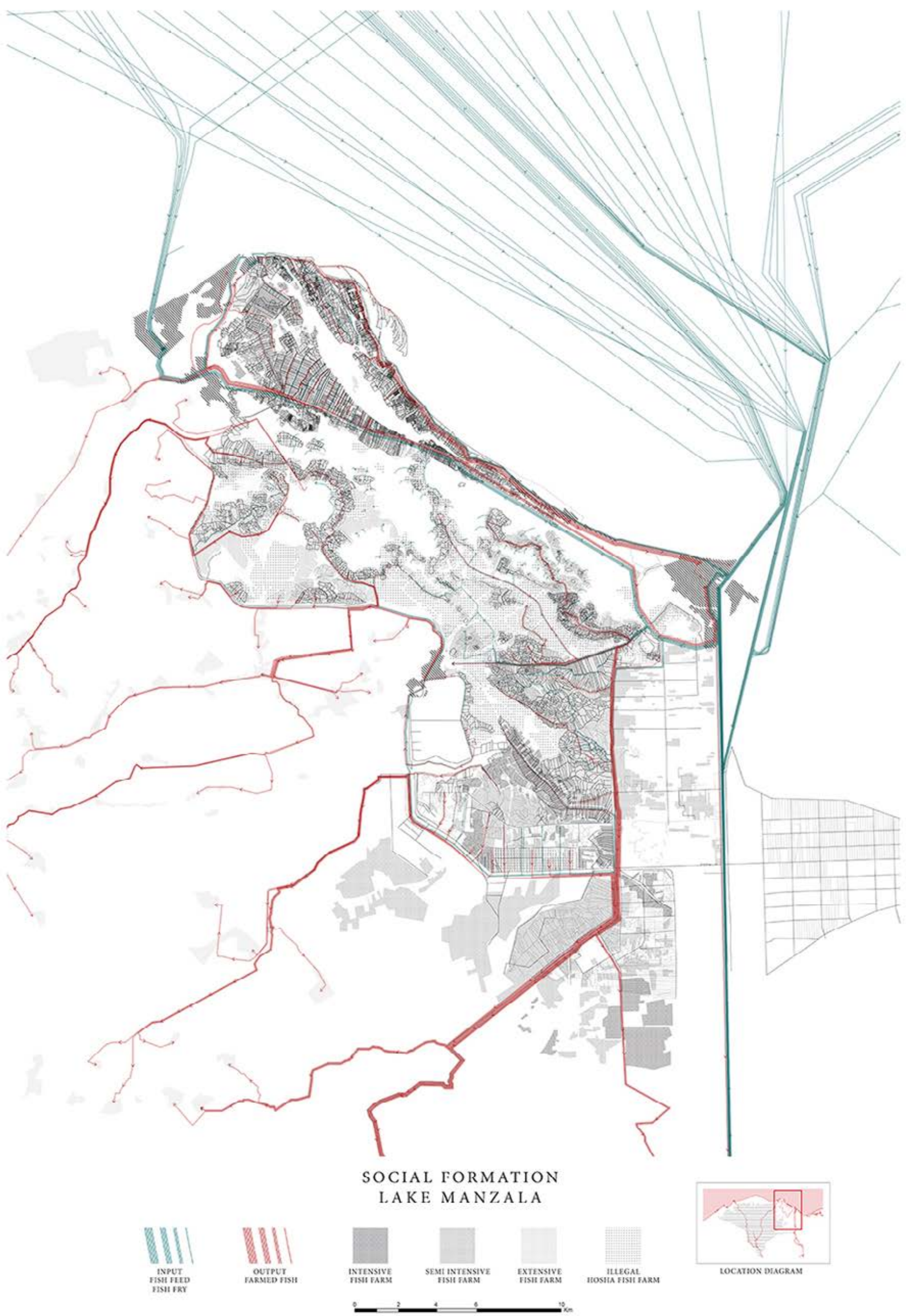




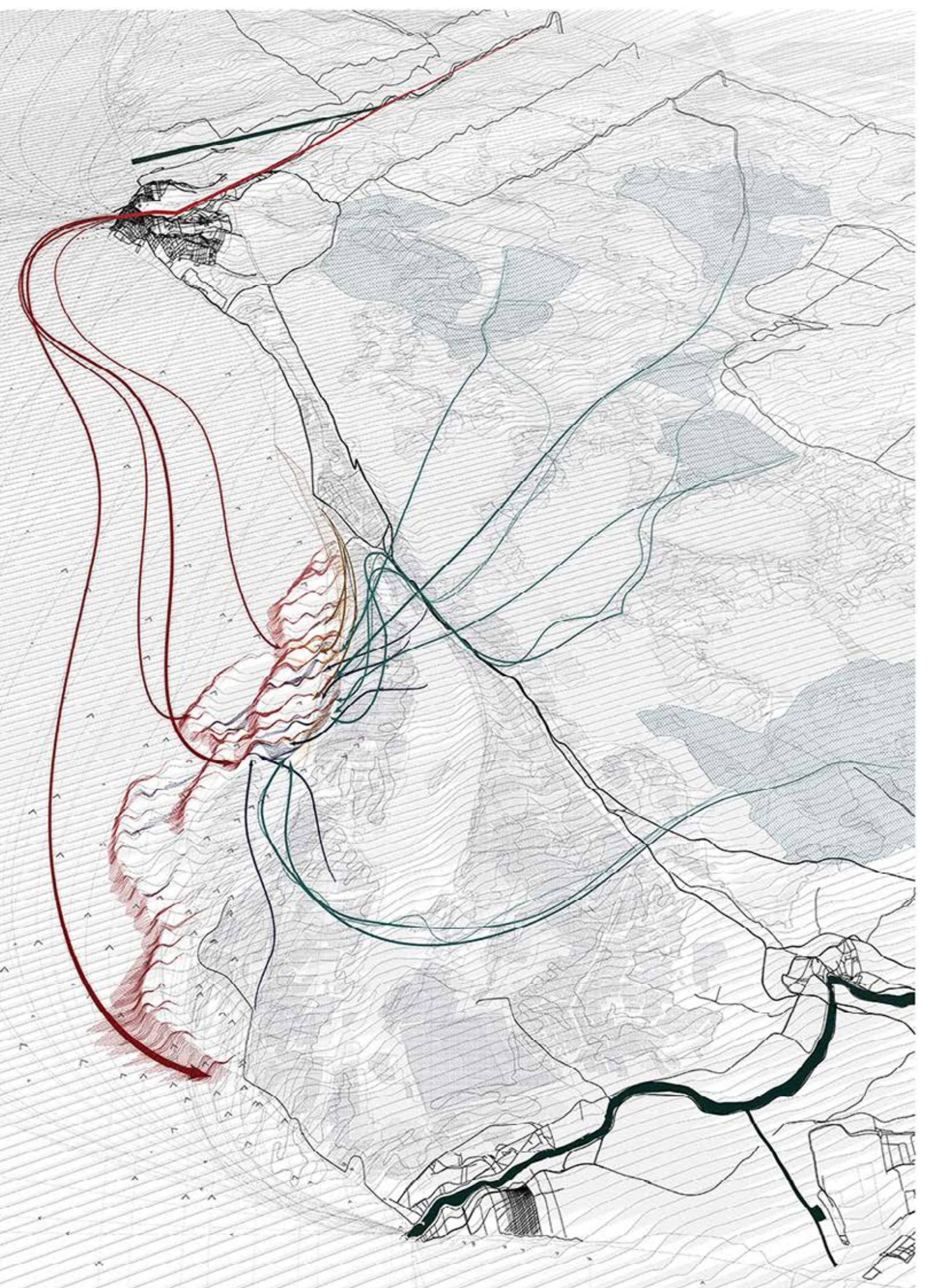

NEGOTIATED TERRITORY

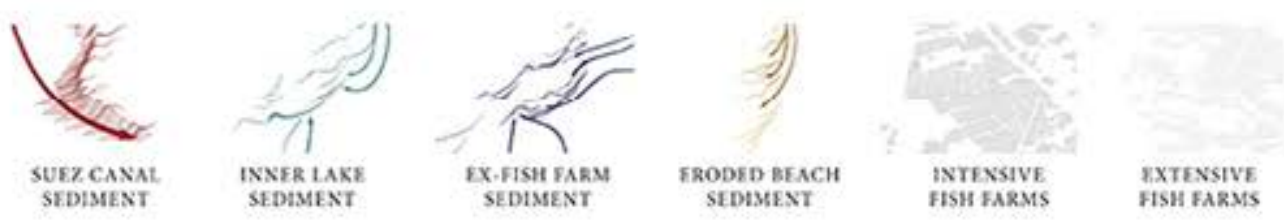


ANGLE TRANSITION

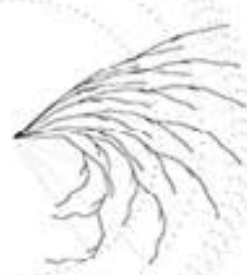

ANGLE GROUPS

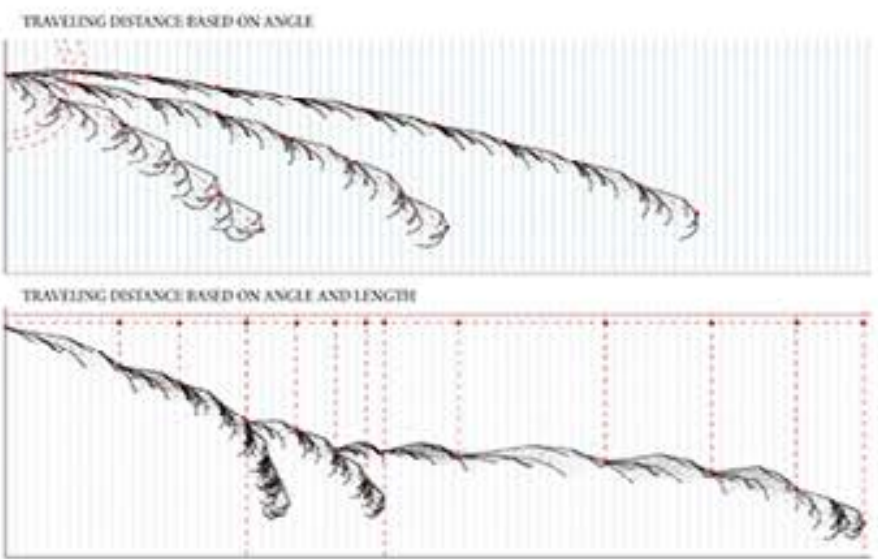

mescatoswm

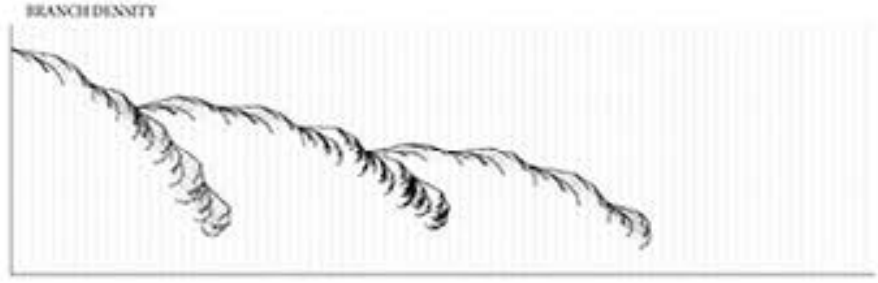

NATURAL CONSTRANTS
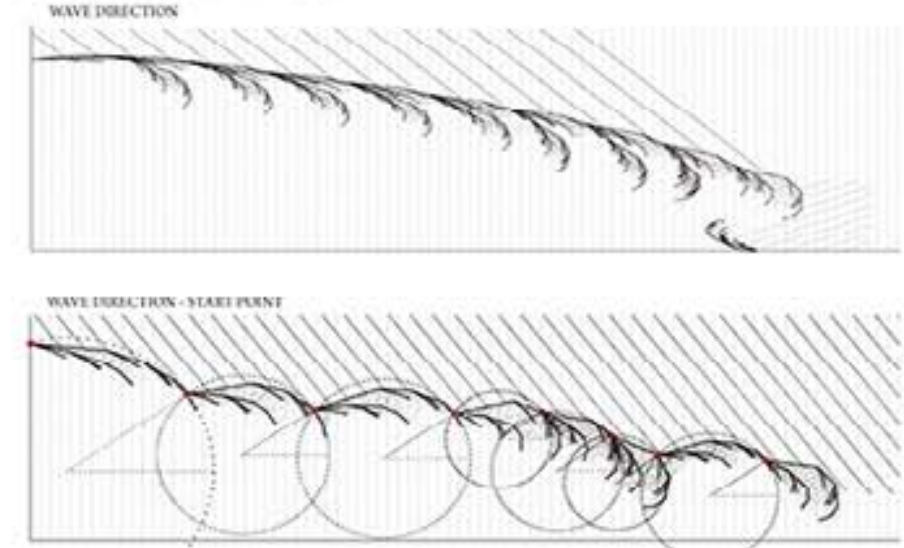

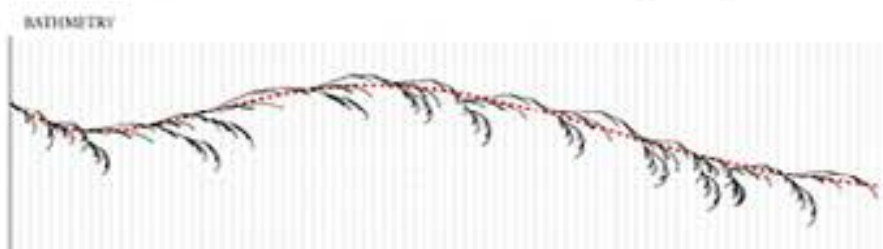

THREE TANSITION ANGLES

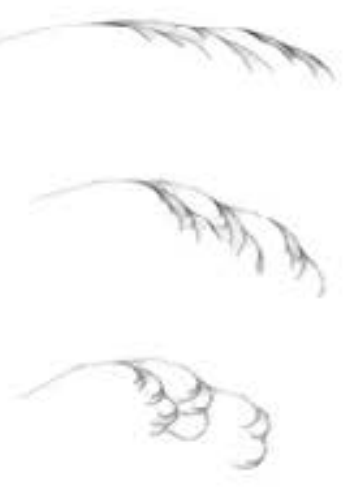

STTE LIMITATION - FISHPOND SIZE

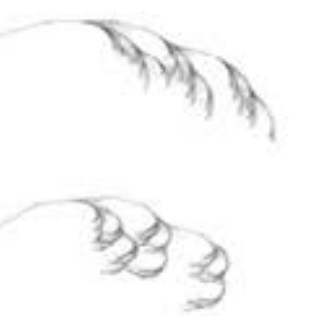

GUIDELINE GENERATING
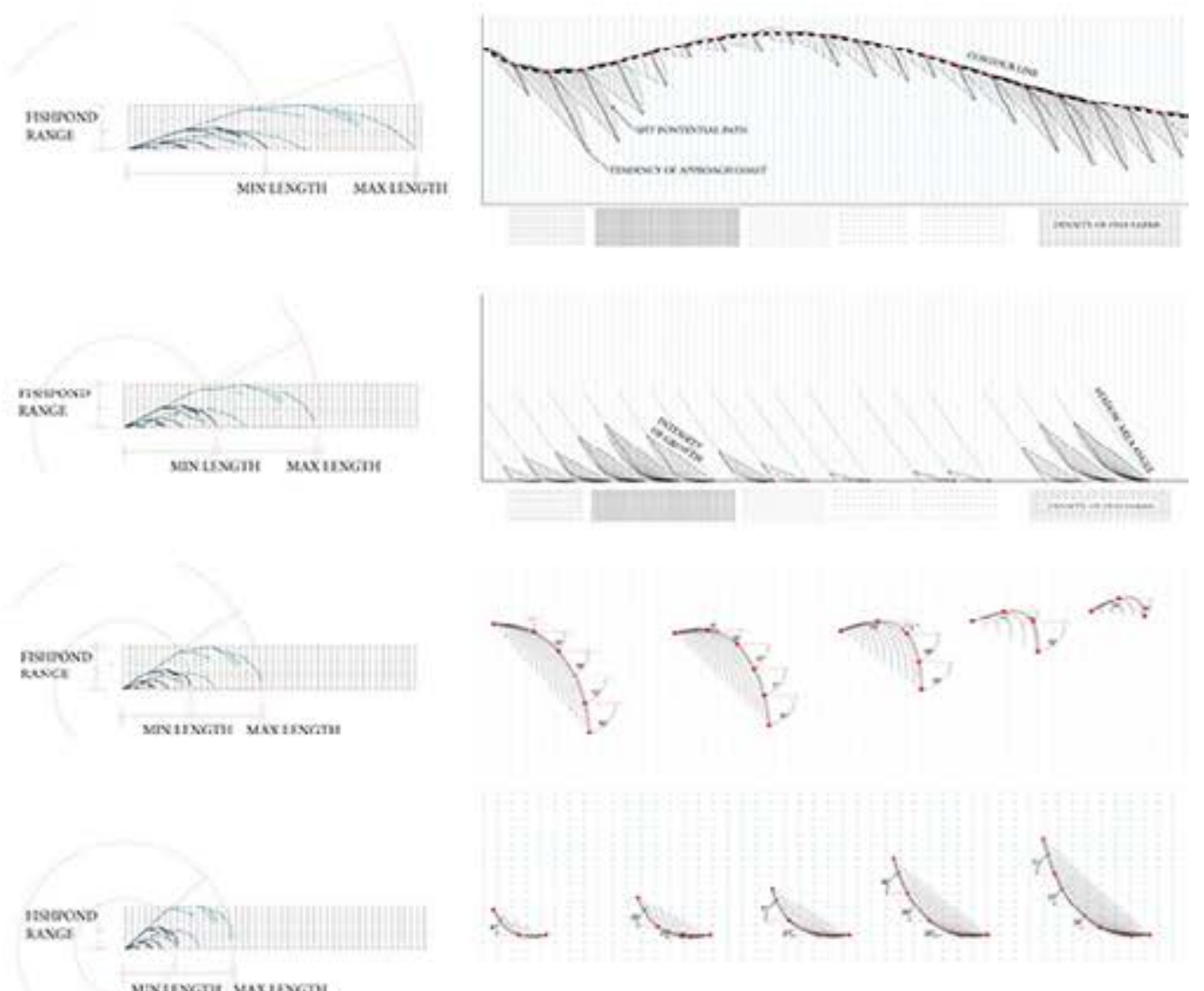

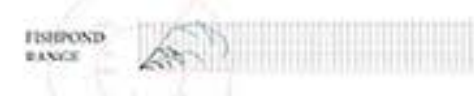

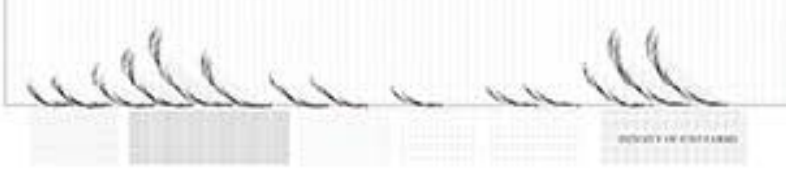

nexar as a

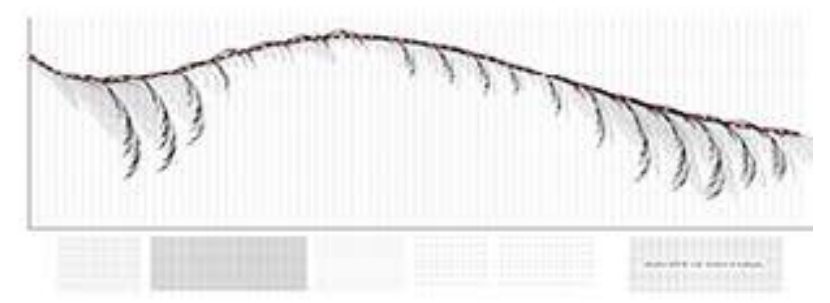

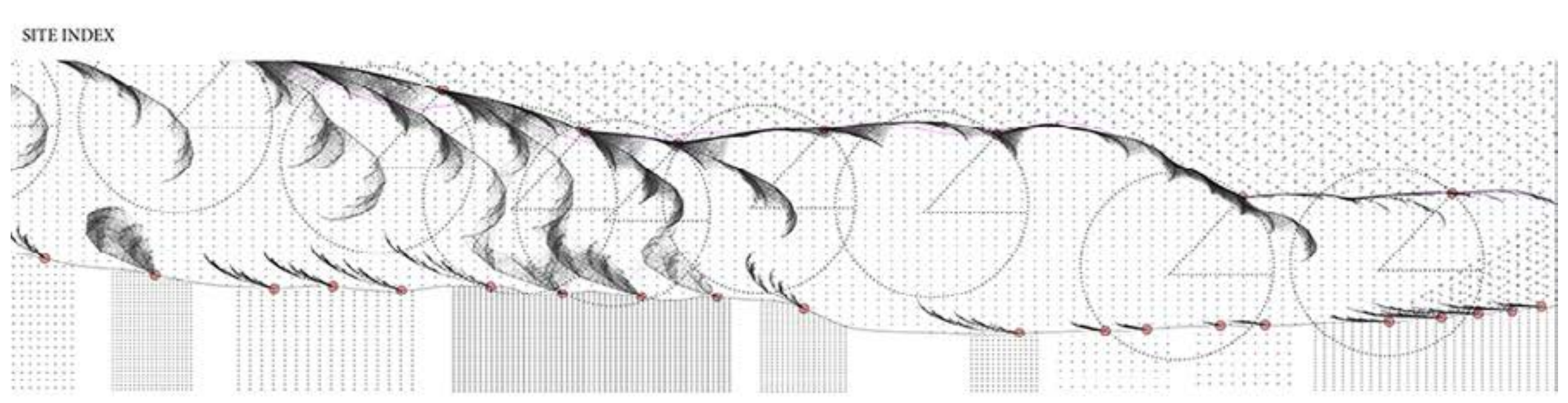




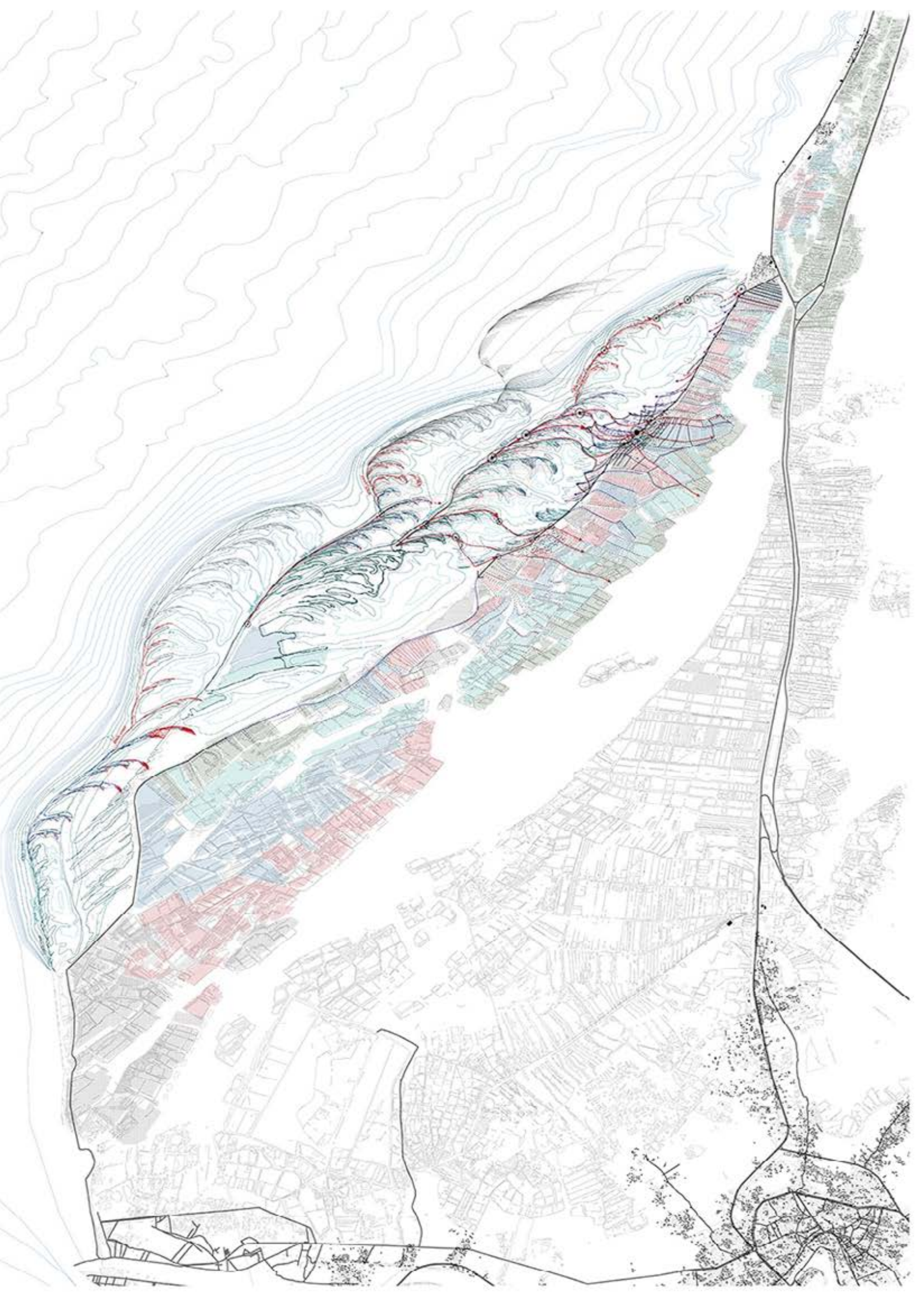

CARTOGENESIS

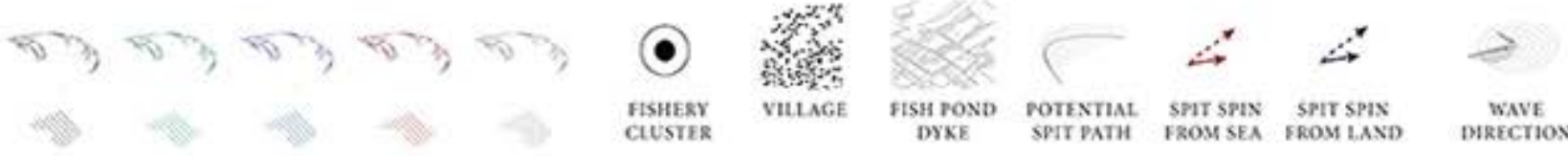

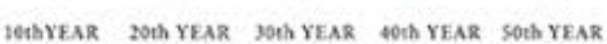



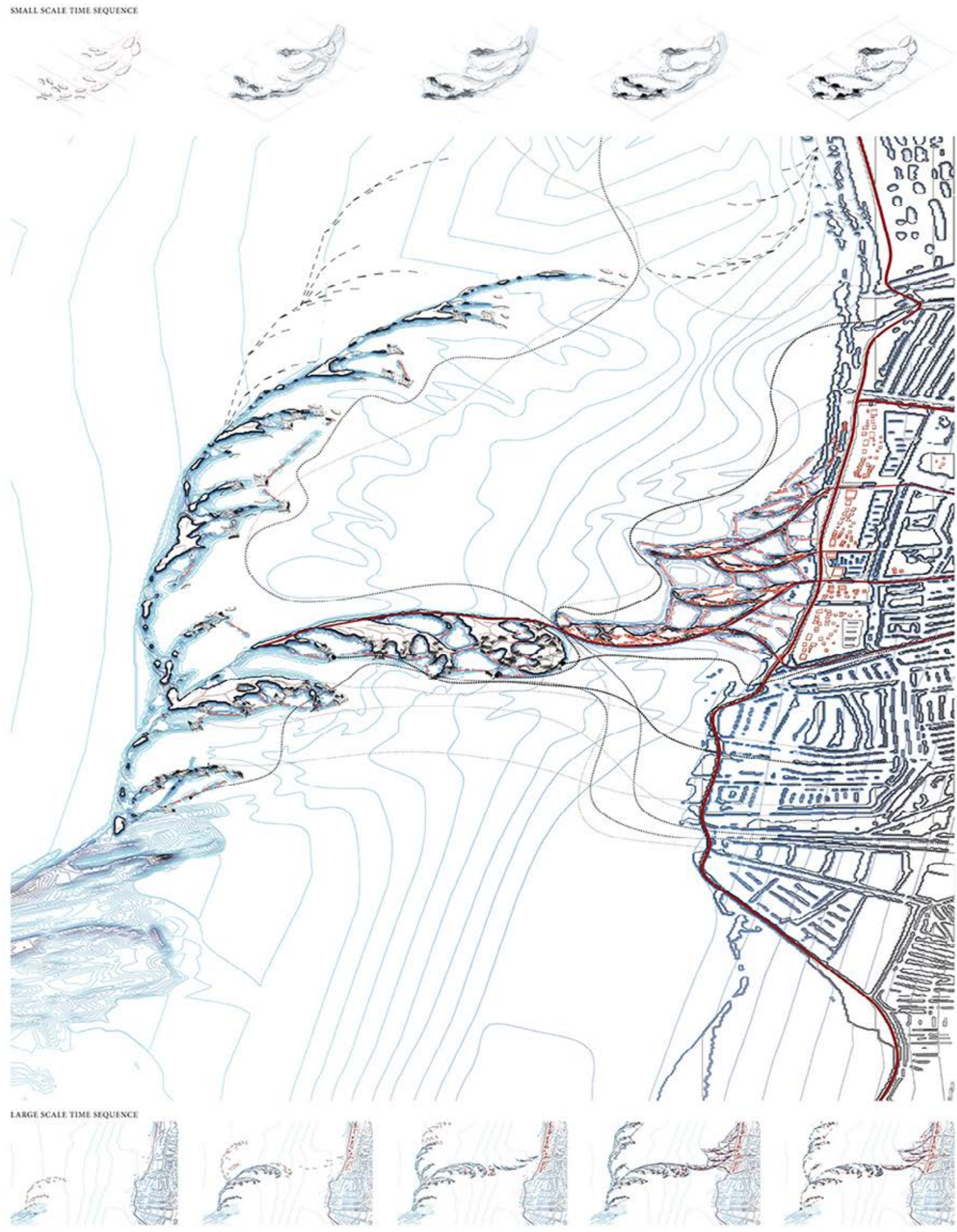

TECTONIC INTERSECTIONS DAMIETTA SPIT

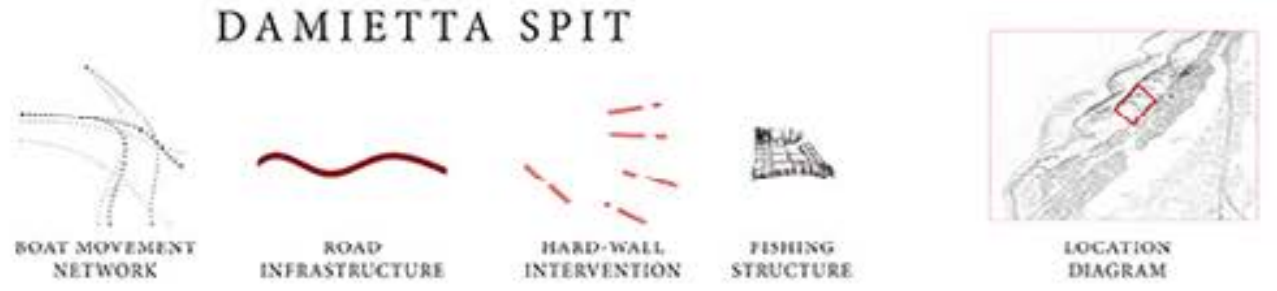

08_ Tectonic Intersections 
Our own proposal is for an artificially provoked coastal spit, fuelled be sediment sources from both the Suez Canal and the inner part of Lake Manzala. This spit could provide both a coastal defence for the existing intensive fish farms and villages while at the same time providing the physical enclosure for smaller scale fish production. Using their own construction techniques, the local fish farmers would deploy their stick and net structures on the spit, both controlling and provoking its movement, forcing it to close into a series of lagoons of varying sizes. This kind of large-scale hacking of an environmental process would occur from the bottom up, but could follow some kind of overall top-down government structuring, so as to guide the consolidation of some areas (for example to protect an existing village) and allow for the gradual erosion of other areas. Littoral Negotiations asks questions about how sediment is managed, how it is redistributed and that perhaps it is something which requires thought from a geomorphological point of view alongside social, economic and political ones. But even more than this, we challenge the traditionally passive role of the architect, suggesting they have the capacity to put forward radical new instruments and mechanisms for how to deal with the issues such as that of a shifting ground.

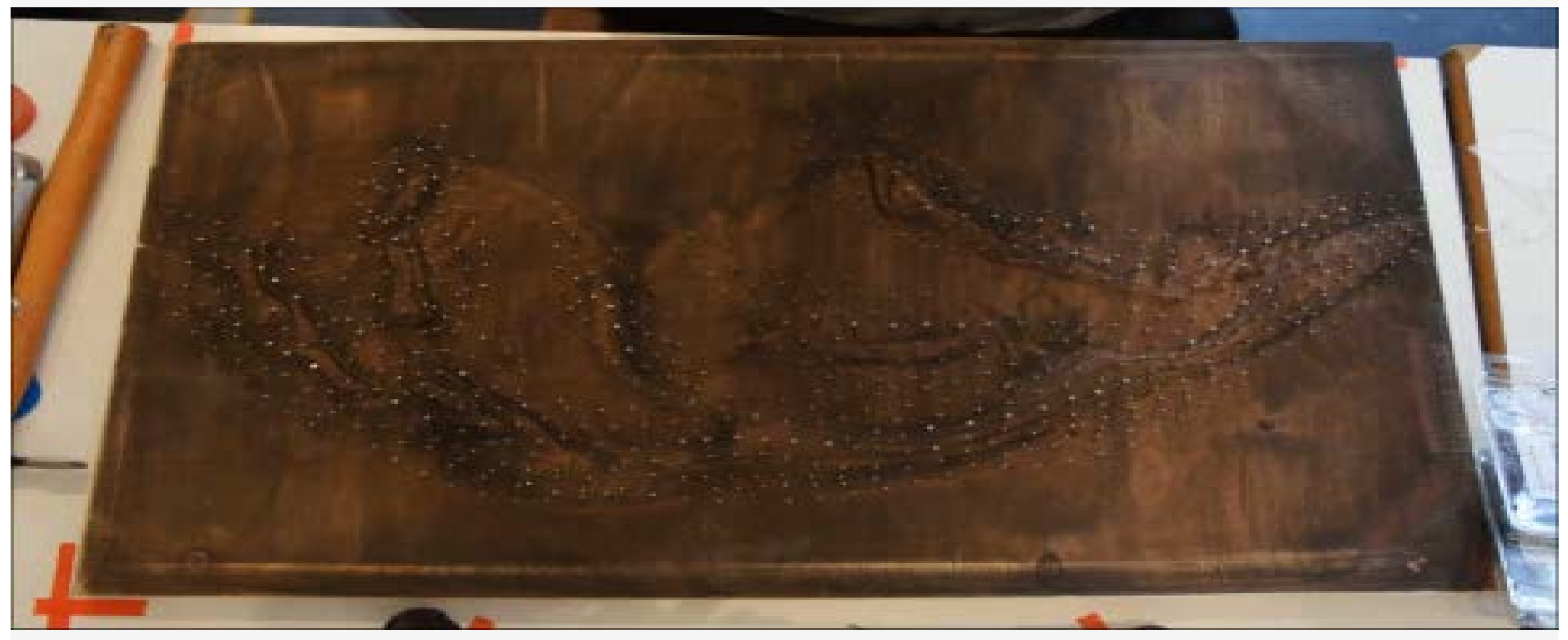




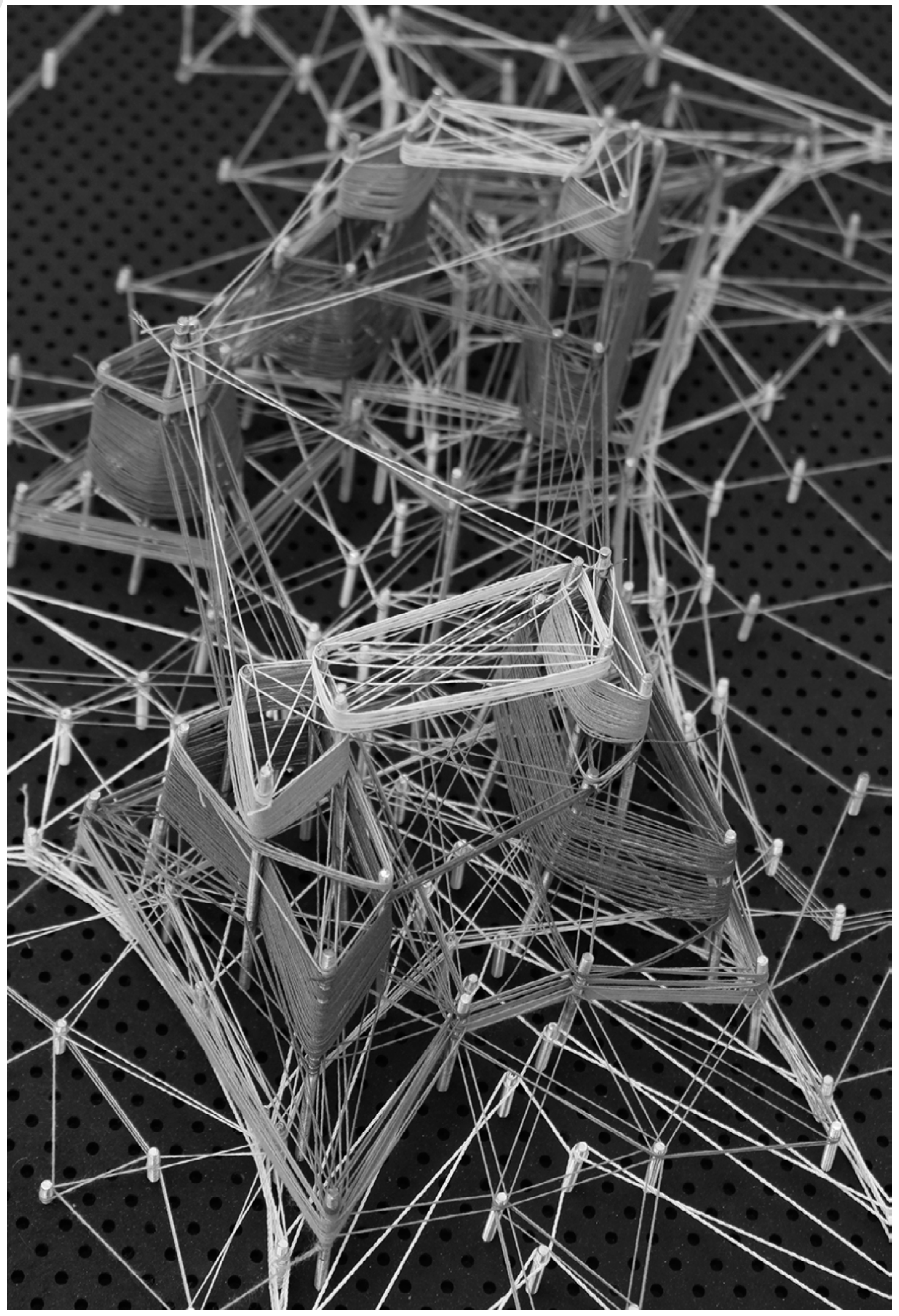

Cooperative Spit Formations $\mathrm{A}$ 

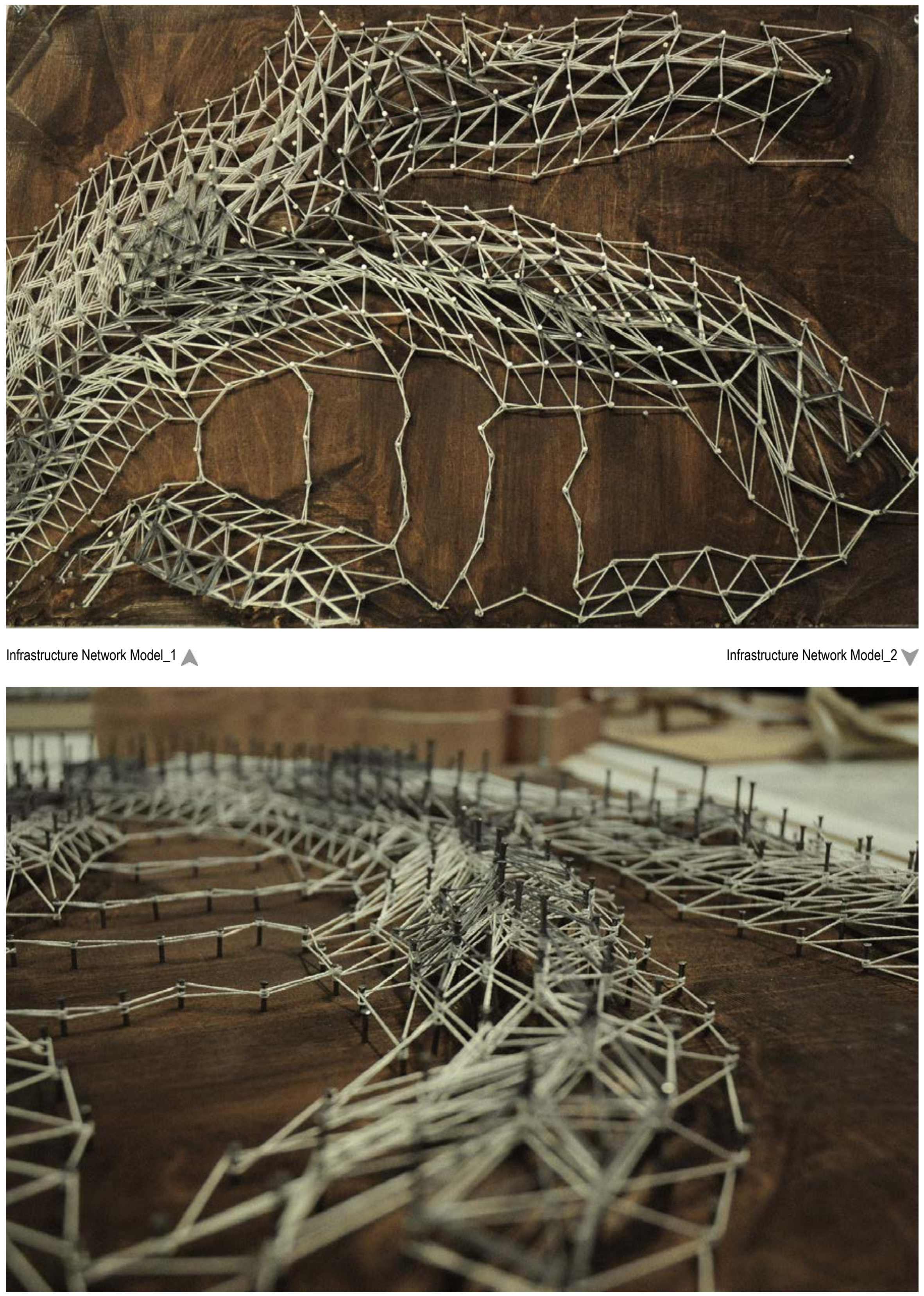


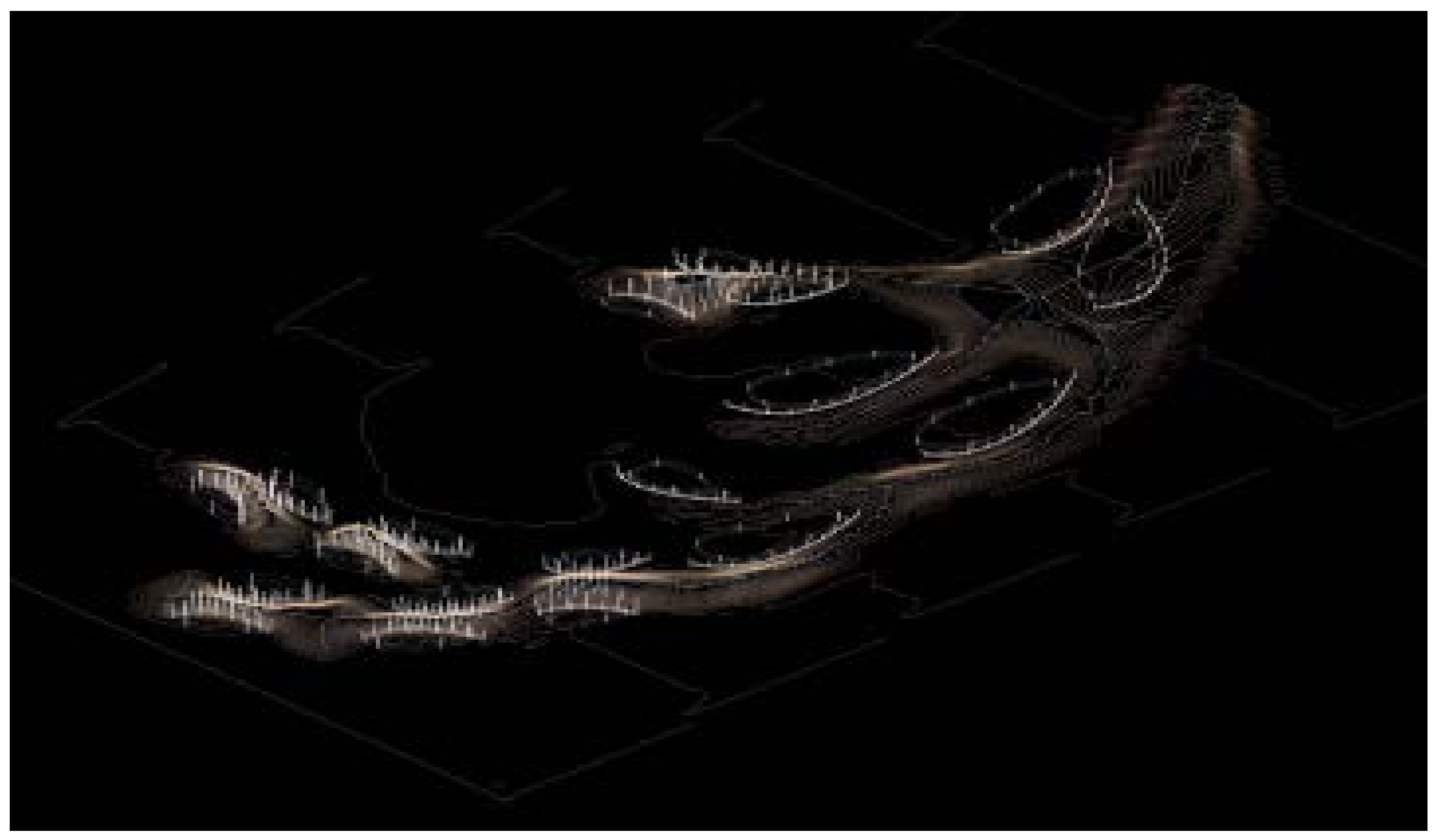

Video Spit Cooperations
Video Catalogue

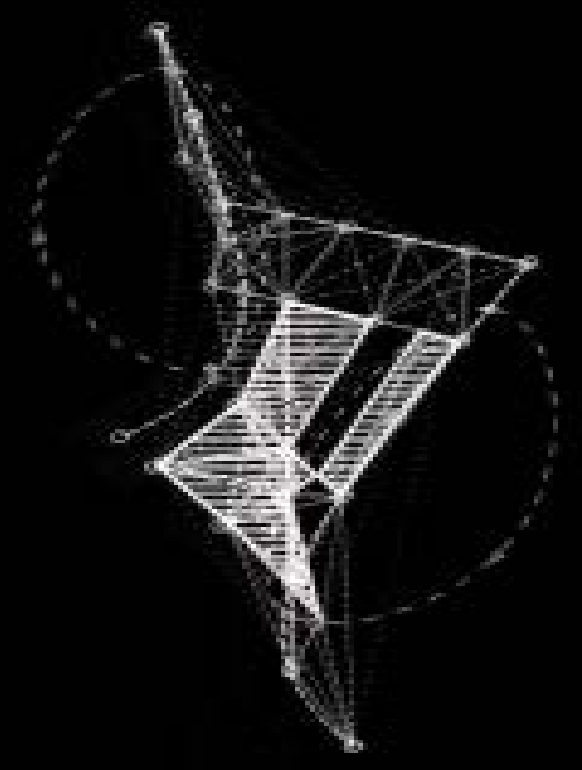



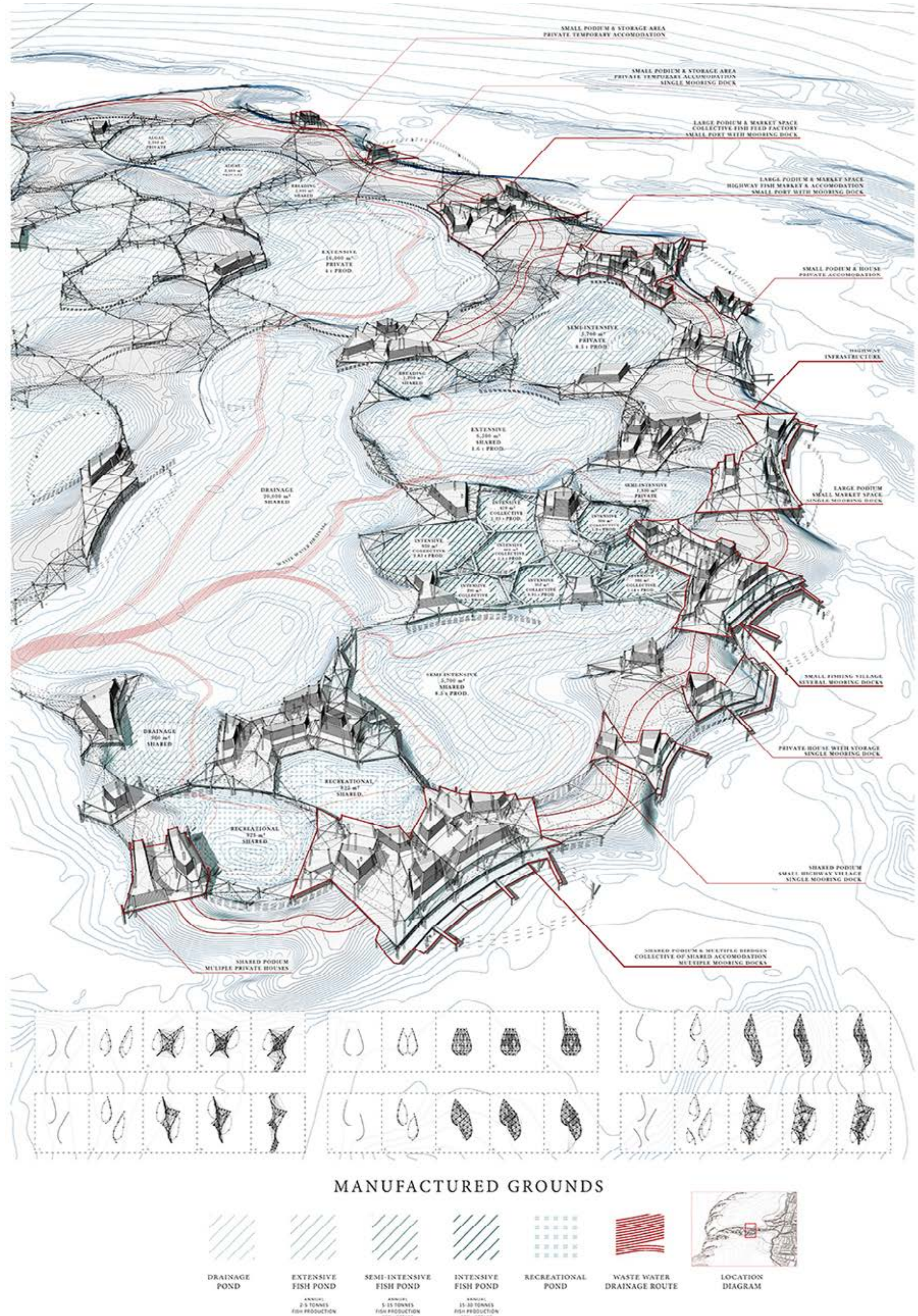


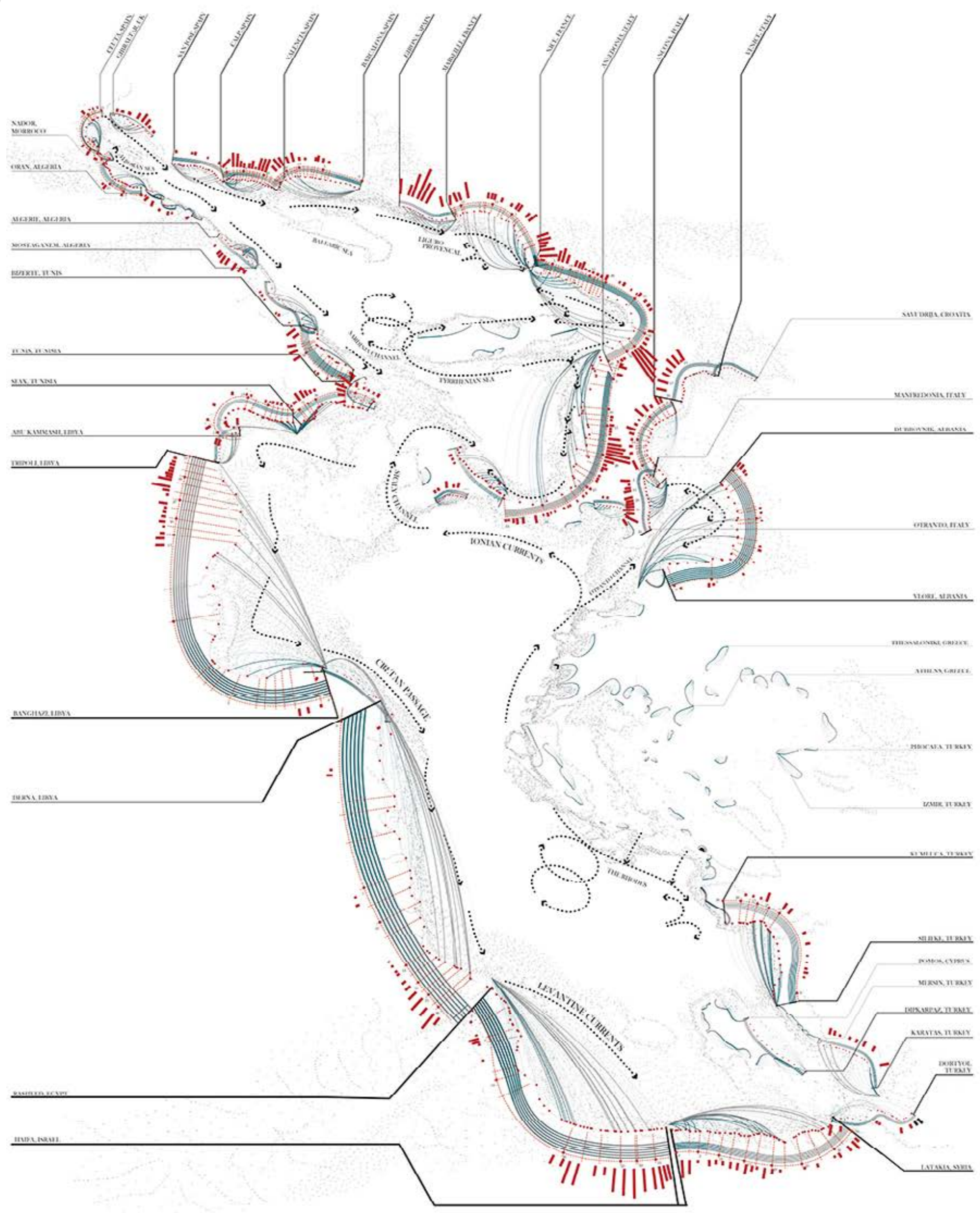

CHARTER FOR SEDIMENTS

IN THE MEDITERRANEAN SEA
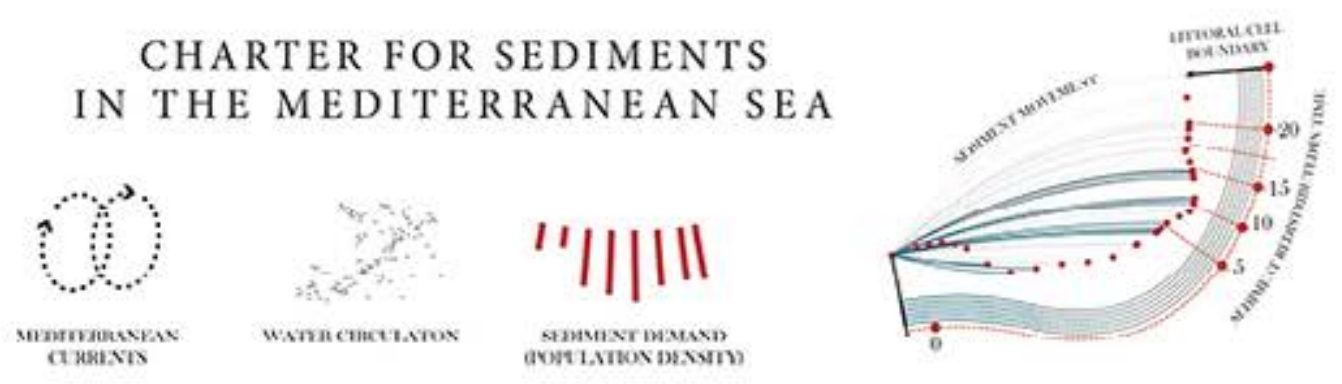


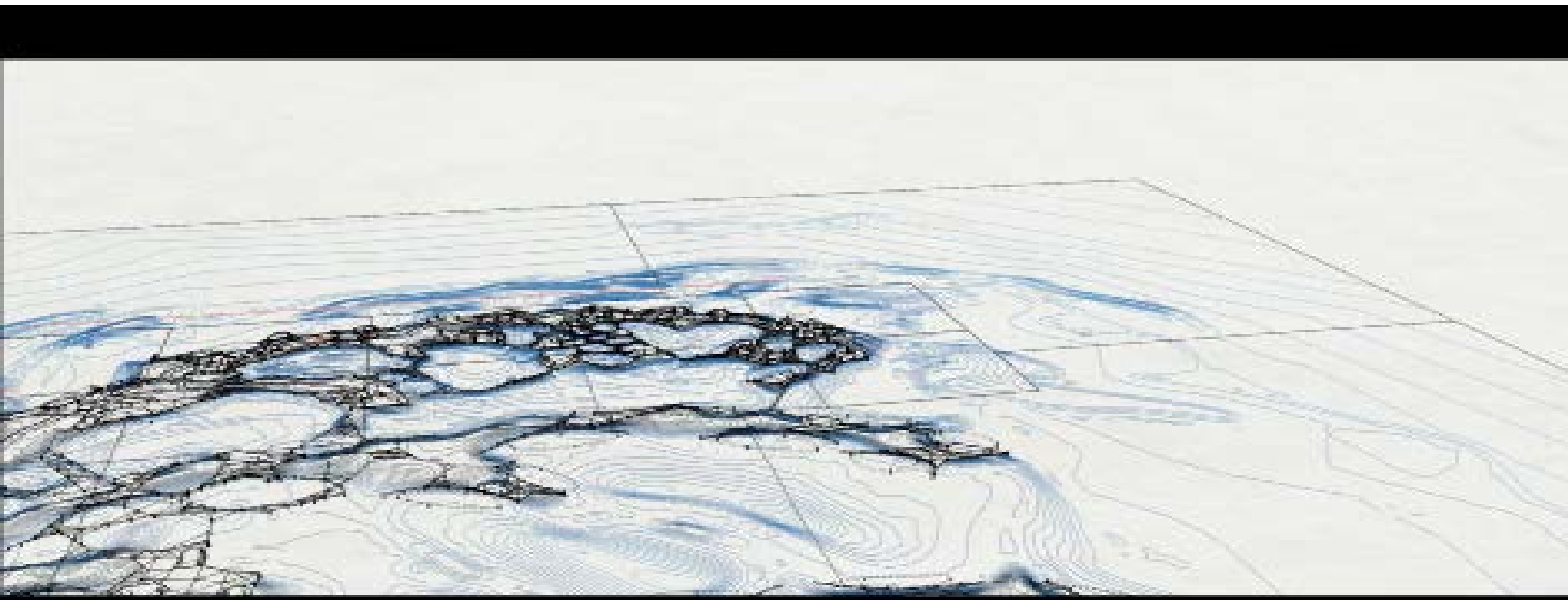

Video Manufactured Grounds Flythrough A

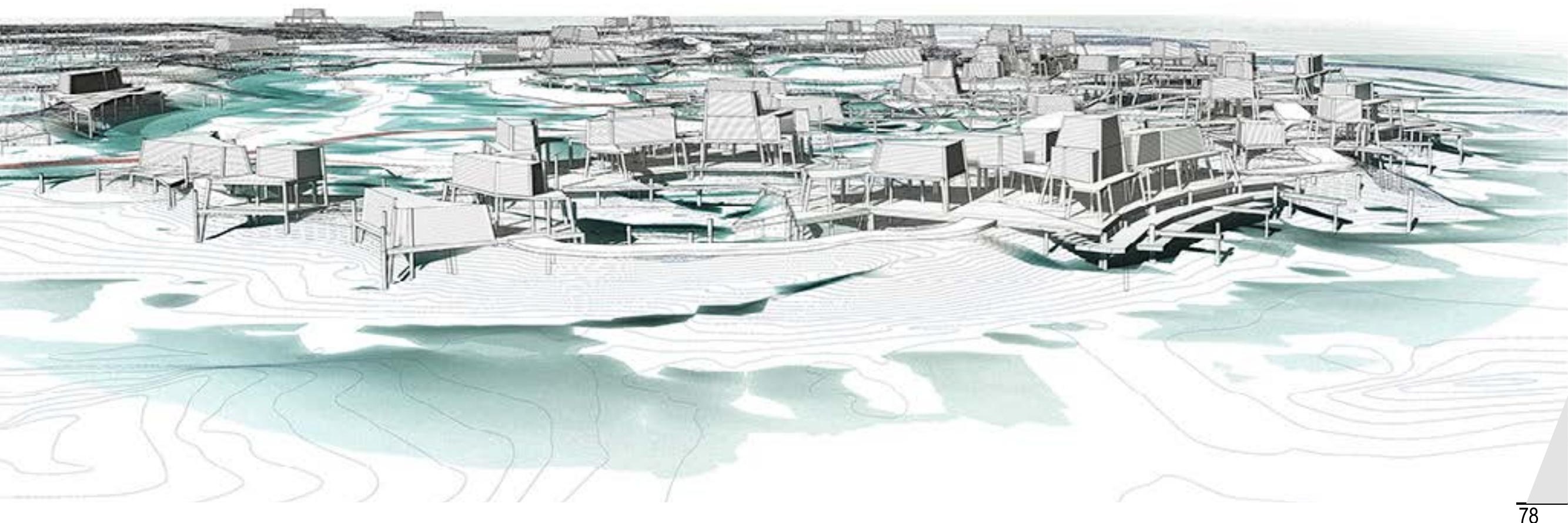

Render_readjust A 


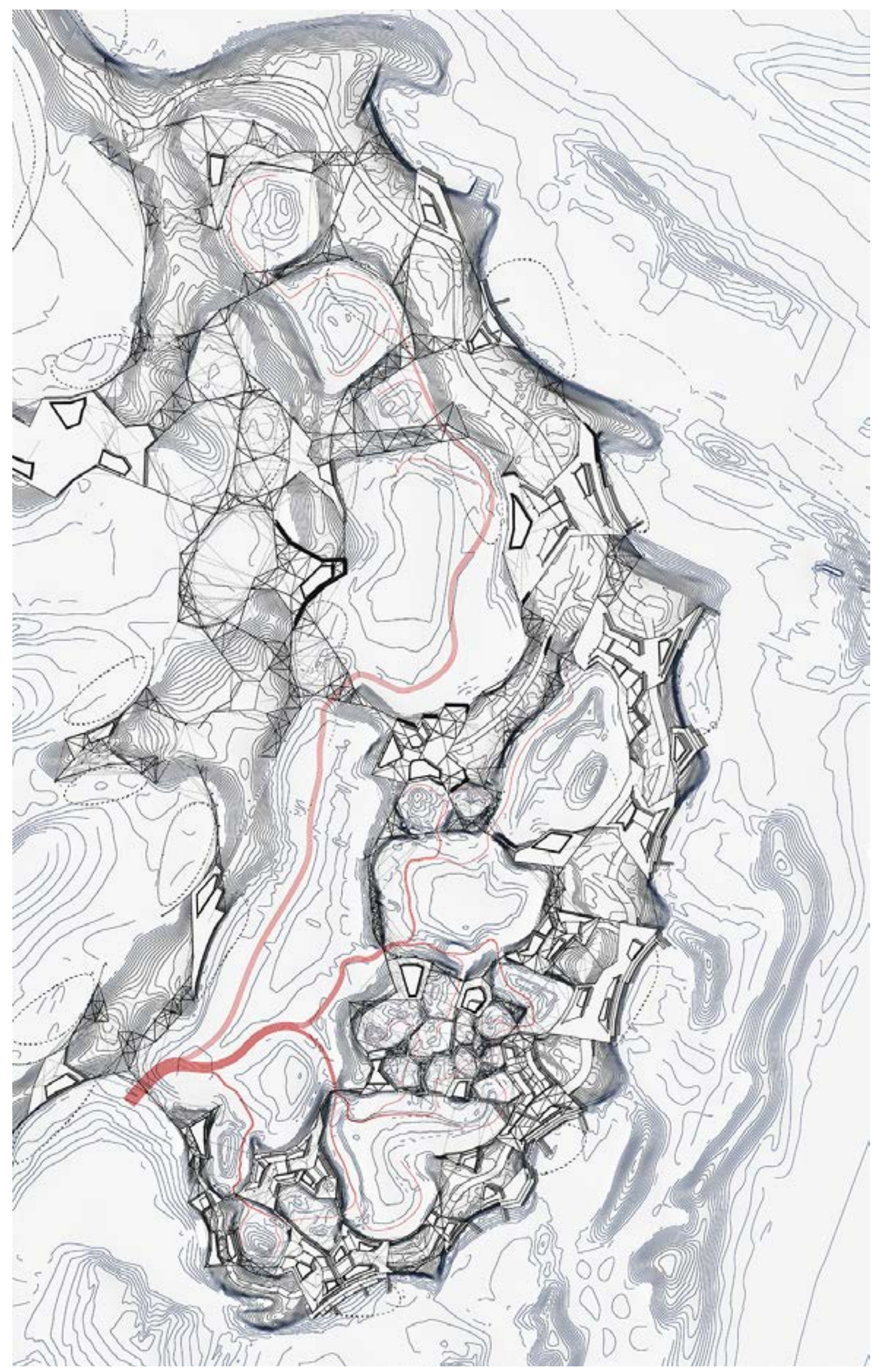

Video Sectional Condition >

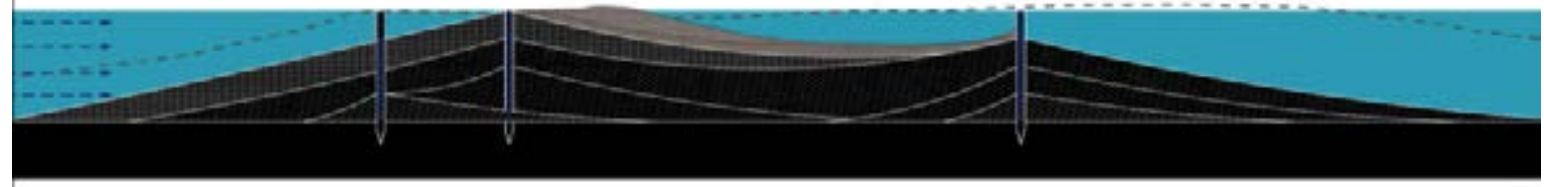

